\title{
The Miocene fossil lizards from Kutch (Gujarat), India: a rare window to the past diversity of this subcontinent
}

\author{
Andrej Čerňanský, ${ }^{1 *}$ (1) Ningthoujam Premjit Singh, ${ }^{2,4}$ Rajeev Patnaik, ${ }^{2}$ K. Milankumar Sharma, ${ }^{3}$ \\ Raghavendra Prasad Tiwari, ${ }^{3}$ Ramesh Kumar Sehgal, ${ }^{4}$ Nongmaithem Amardas Singh, ${ }^{3}$ \\ and Deepak Choudhary ${ }^{2}$

\begin{abstract}
${ }^{1}$ Department of Ecology, Laboratory of Evolutionary Biology, Comenius University in Bratislava, Faculty of Natural Sciences, Mlynská dolina, Ilkovičova 6,84215 Bratislava (Slovakia) <cernansky.paleontology@gmail.com>

${ }^{2}$ Department of Geology (CAS), Panjab University, Chandigarh-160014, India <ningthoujampremjit11@gmail.com>, <rajeevpatnaik@ gmail.com>, <deepakc015.dc@gmail.com>

${ }^{3}$ Department of Geology, Central University of Punjab, Bathinda-151401, India <milankumar.sharma@gmail.com>, <rptmzu@ rediffmail. com>, <nongmaithemamardassingh@hotmail.com>

${ }^{4}$ Wadia Institute of Himalayan Geology, Dehradun-248001, India <rksehgal@ wihg.res.in>
\end{abstract}

\begin{abstract}
The Miocene beds of Kutch in India are well known for their mammalian assemblages, including the extinct ape Sivapithecus, but far less is known about the fossil squamates from this area. Although India with its over 800 reptile species is recognized as one of the global biodiversity hotspots, knowledge of past diversity and paleobiogeography of squamates on this subcontinent is very limited. We here report on new lizard finds, which have been recovered from two stratigraphic levels: the older Palasava locality (dated to the middle Miocene, ca. $14 \mathrm{Ma}$ ) and the younger Tapar site (late Miocene, ca. 11-10 Ma). Although fragmentarily preserved, the material described here sheds important light on the composition and paleobiogeography of squamates during the Miocene in South Asia. The older Palasava locality contains cf. Uromastyx s.l. and Varanus sp., the latter representing the oldest record of this taxon in the region of India south of the Himalayas and its occurrence here suggests a mean annual temperature not less than $15^{\circ} \mathrm{C}$. The material from the younger Tapar locality consists of an unidentified acrodontan lizard, here questionably placed in agamids, and a skink. The latter shows a resemblance to mabuyines, however, the fragmentary nature of the material does not allow a precise allocation without doubts. The cosmopolitan mabuyines have been suggested to have their origin in Asia, so the potential presence of mabuyines in the Tapar locality might represent the first, but putative, Asian evidence of the occurrence of this group in the Miocene.
\end{abstract}

\section{Introduction}

We here describe lizard assemblages, which recently have been collected from the middle Miocene Palasava and the late Miocene Tapar localities of Kutch, Gujarat. Although this region is well known for its fossil mammals and other vertebrate fauna (Wynne, 1872; Lydekker, 1876, 1880; Prasad, 1962, 1964, 1967; Sahni and Mishra, 1975; Thewissen and Bajpai, 2009; Bajpai et al., 2010; Bhandari et al., 2010, 2015, 2018; Patnaik et al., 2014; Singh et al., 2019, 2020; Kapur et al., 2021; Sharma et al., 2021), very little is known about the fossil squamates of the region-only several fossil snakes have been reported previously (Head et al., 2007; Rage et al., 2008; Kapur et al., 2021). However, India has an immense diversity of herpetofauna today, with 801 reptile species contributing to its recognition as a mega-diverse country and one of the global biodiversity hotspots (e.g., Myers et al., 2000; Palot, 2015; Uetz

\footnotetext{
*Corresponding author
}

et al., 2021). Major lizard clades in the Indian region (see Mausfeld et al., 2002; Uetz et al., 2021) include geckos (e.g., Hemidactylus, Cyrtodactylus, Dravidogecko), agamids (e.g., Calotes, Saara, Laudakia, Sitana), chameleons (Chamaeleo zeylanicus Laurenti, 1768), skinks (Eutropis, Ablepharus, Lygosoma), and varanids (Varanus). But despite this high diversity, pre-Quaternary fossil records of lizards have been documented only occasionally from this subcontinent. This leads to a poor understanding of squamate history in this biogeographically interesting area during the Miocene, a time period that strongly influenced the characteristics of India's modern ecosystems.

One of the lizard clades with a better-documented history on this subcontinent is the acrodontan lizards. Agamids have been described from the lower Eocene of the Vastan Lignite Mine (Prasad and Bajpai, 2008), where a high diversity of acrodontan lizards was observed (Rana et al., 2013), including Tinosaurus indicus Prasad and Bajpai, 2008. Later, the dentary of this taxon was also described from the early Eocene Tadkeshwar locality (Smith et al., 2016). However, there is a significant gap in regards to this clade in the Neogene-subsequent fossil 
herpetofaunas from India come from the Plio-Pleistocene and are represented by Uromastyx and Calotes from the Upper Siwaliks (Raghavan, 1991; Patnaik and Schleich, 1998). The solitary report of an agamid from the central Narmada valley indicates the continuity of this clade in the Quaternary. The material was described by Joshi and Kotlia (2010) as a new species, Agama schleichi (note, however, that the type material of this species is represented only by jaw fragments with general rather than unique tooth morphology; the problem is that tricuspid teeth of a similar form are present in many species of Agamidae; e.g., Smith et al., 2011). Note that Tikiguania estesi Datta and Ray, 2006, from the Tiki Formation, originally described as a Triassic lizard, is considered now as a Quaternary or late Tertiary agamid rather than Triassic in age (Hutchinson et al., 2012). With regard to chamaeleonids, cranial remains potentially belonging to these unusual lizards have been reported from the late Miocene Haritalyangar locality (Sankhyan and Čerňanský, 2016).

As for varanids, Varanus sivalensis Falconer, 1868, has been described from Pliocene to Early Pleistocene deposits of Siwalik (Falconer, 1868; Lydekker, 1888). The Miocene record of this clade in India is represented by the material of Varanus sp. from the late Miocene of Raun, Jammu (Rage et al., 2001) and Varanidae indet. from the middle part of the early Miocene lower Murree Group in northwest Himalaya (Kumar and Kad, 2003).

The new lizard assemblages described in the present paper provide the opportunity to document additional crucial data about the herpetofaunal diversity in India during the Miocene, which should prove useful for future analyses of past squamate diversity and faunal biogeography. The distribution of these previously unknown lineages in the fossil record from this area are discussed here as well.

\section{Geological setting}

The Kutch basin of India has yielded vertebrate and invertebrate fossils ranging from Mesozoic to Pleistocene in age (Biswas, 1992, and reference therein). In this basin, Cenozoic sediments are deposited over the Deccan traps, which overlie older Mesozoic sediments. The Neogene deposits of Kutch are divided into the Khari Nadi, Chhasra/Gaj, and Sandhan formations (Biswas, 1992; Geological Survey of India, 2012). The Khari Nadi Formation, dated as early Miocene (23.03-20.43 \pm $0.05 \mathrm{Ma}$ ) (Gradstein et al., 2004; Patnaik et al., 2014), comprises laminated to very thin bedded siltstone, fine-grained sandstone, and gypseous claystone, and is considered to have a conformable and gradational contact with the younger Gaj/ Chhasra Formation and a weak erosional unconformity with the underlying Oligocene Maniyara Fort Formation (Biswas, 1992; Catuneanu and Dave, 2017; Sharma et al., 2021). The lithologies of the Chhasra/Gaj Formation, which are dominated by olive green shale, gypseous shale, and claystone alternating with thin argillaceous limestone beds, has a disconformable contact with the younger Sandhan Formation (?Miocene-Pliocene; Fig. 1; Biswas, 1992; Catuneanu and Dave, 2017). Biswas (1992) assigned an early Miocene age (Burdigalian) for the rocks of Gaj/Chhasra Formation, however the Geological Survey of India (2012) preferred to assign an age ranging from early to middle Miocene. The Sandhan Formation comprises wellsorted, medium- to coarse-grained, massive, micaceous
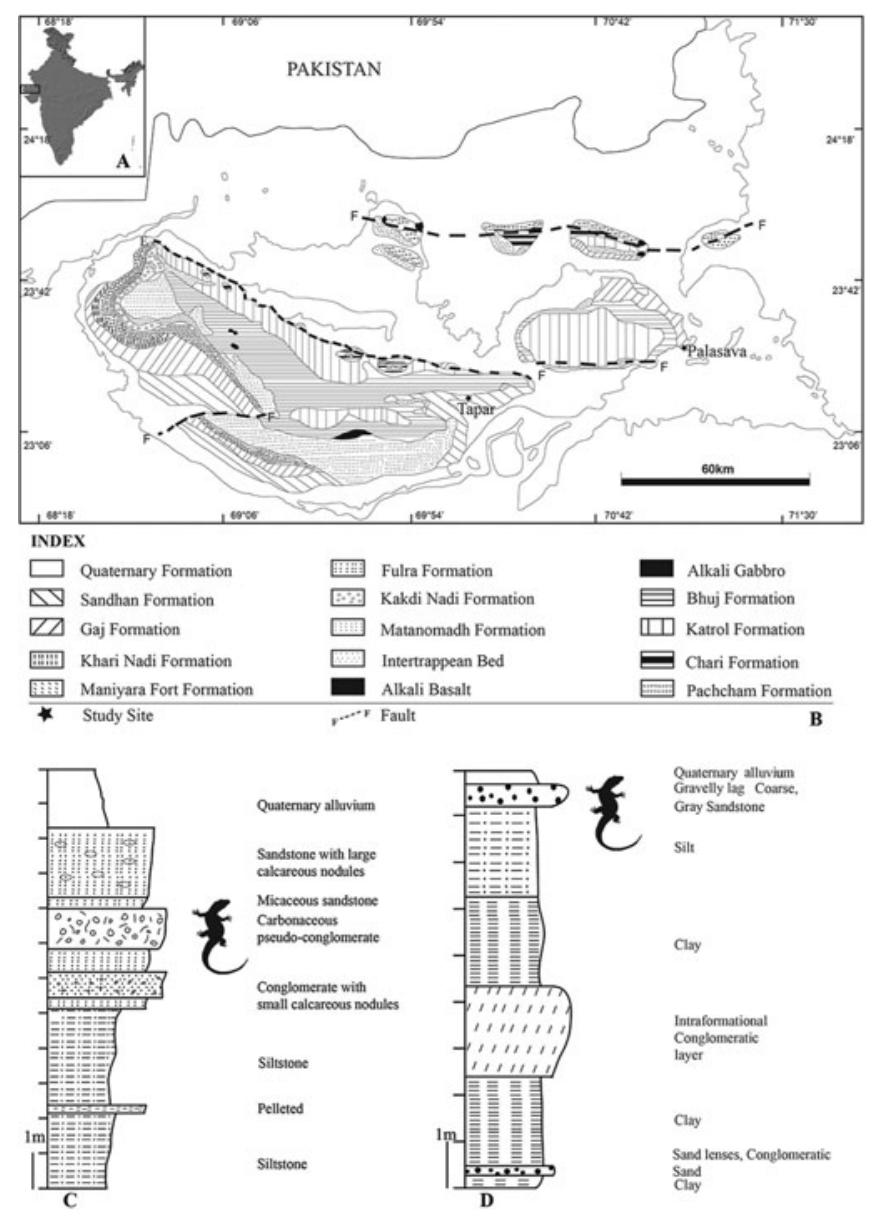

Figure 1. Location of the studied material. (1) Map of India showing the study locality (represented by rectangular box); (2) geological map of Kutch (Geological Society of India, 2012); (3) stratigraphic column of the Tapar locality; (4) stratigraphic column of the Palasava locality. Shaded tetrapod figures indicate stratigraphic levels from which specimens were collected.

sandstones, laminated siltstones, and claystone, with lenticular bodies of conglomerates, calcareous grits, and grayish mottled silty sandstone with calcareous nodules (Biswas, 1992).

The present lizard assemblages were collected from the late Miocene conglomeratic beds of the Tapar site belonging to Sandhan Formation, and from the middle Miocene Palasava locality of the Gaj/Chhasra Formation (Fig. 1). The Tapar section comprises massive sandstone, siltstone, and clay beds alternating with intermittent conglomerate beds composed of calcareous nodules, agate pebbles, very coarse-grained sand, and mud clasts (Fig. 1). This conglomerate bed is richly fossiliferous and yields a variety of vertebrates, including the hominoid Sivapithecus, fragmented teeth of proboscideans (Deinotherium, Gomphotherium), rhinos, giraffids, equids, bovid, suids, rodents, turtles, crocodiles, teleosts, sharks, and batoids (Bhandari et al., 2010, 2015, 2021; Singh et al., 2019, 2020; Sharma et al., 2021). The Tapar section has been dated as basal late Miocene (ca. 11-10 Ma) age based on the First Appearance Datum (FAD) of Hipparion and associated mammalian faunas (Bhandari et al., 2015). The lithosection of the Palasava locality consists predominantly of clay, silt, and sandstone and conglomerate alternating with successive deposits of coarse-grained sandstone and gravelly lag deposits at the top 
(see Fig. 1). The Palasava section, dated as middle Miocene (Kapur et al., 2021), has yielded a diverse mammalian fauna, including Sanitherium, Sivameryx, Brachypotherium, Zygolophodon, Gomphotherium, and Deinotherium, along with teleosts, sharks, batoids, turtles, crocodiles, snakes, and birds.

\section{Materials and methods}

The present fossil lizard remains were recovered from the late Miocene of Tapar and middle Miocene Palasava localities during the field season from 2017-2019. Medium-sized jaws were recovered from surface collection during the field work, and small-sized lizards were obtained from calcareous ferruginous conglomerate by screen-washing. The fossils were photographed with a Leica Stereozoom Microscope housed at the Department of Geology, Panjab University, Chandigarh, India. All described materials from the two localities are housed in the Department of Geology, Panjab University, Chandigarh and Department of Geology, Central University of Punjab under the collection codes: VPL/PU/KT, VPL/PU/KPS, BIOPS/CUP/KT, and BIOPS/CUP/KP.

The standard anatomical orientation system is used throughout this paper, and terminology describing individual bone structures is based on Rage and Augé (2010) and Čerňanský (2010, for acrodont lizards). As for taxonomy of skinks, we use the term Scincidae here in its preferred family level usage for these lizards (see Uetz et al., 2021), in contrast to the classification proposed by Hedges, 2014.

Repositories and institutional abbreviations._-VPL/PU/KT, Vertebrate Palaeontology Laboratory/Panjab University/Kutch Tapar; VPL/PU/KPS, Vertebrate Palaeontology Laboratory/Panjab University/Kutch Palasava; BIOPS/CUP/KT, Biostratigraphy, Palaeontology and Sedimentology Laboratory/Central University of Punjab/Kutch Tapar; BIOPS/CUP/KP, Biostratigraphy, Palaeontology and Sedimentology Laboratory/Central University of Punjab/Kutch Palasava.

\section{Systematic paleontology}

Squamata Oppel, 1811

Iguania Cope, 1864

Acrodonta Cope, 1864

Agamidae Spix, 1825

Uromastycinae Theobald, 1868

Genus Uromastyx Merrem, 1820
Type species.-Stellio spinipes Daudin, 1802 (=Uromastyx aegyptia [Forskål, 1775]) is the type species of the genus Uromastyx Merrem, 1820.

\section{cf. Uromastyx s.l. sp. Figure 2}

\section{Occurrence.-Palasava, middle Miocene.}

Description.-A right dentary is partially preserved (Fig. 2), lacking anterior and posterior terminations. The dentary is relatively short and robust, being deep ventrally; however, the posterior half of the ventral margin is strongly damaged. The Meckelian canal is fully open, being widely open posteriorly. It is roofed by a robust supra-alveolar shelf. The anteriormost portion of the dentary is broken off, thus the symphysis is not preserved; however, it can be estimated, based on the anterior preserved portion of the shelf, that the symphyseal region was strong because the anterior region of the shelf widens relative to the mid-region of the shelf. The posteroventral region of the shelf is broken off. A longitudinal groove appears to be present. It can be very likely interpreted as the dental groove, although this region is highly weathered (it is not clear whether it is a real structure or the result of a linear fracture; see Remarks). It seems to be somewhat narrow, forming a shallow furrow ventral to the subdental shelf. The subdental shelf bears teeth (14 tooth positions are still present). The lateral surface of the dentary is smooth. One elliptical labial foramen is located at the level of the seventh tooth position (counted from posterior). Others cannot be adequately identified; note, however, that the surface is covered by a calcite crust and sedimentary rock in several places. Posteriorly, the basal portion of the coronoid process is preserved, starting to rise dorsally at the end of the tooth row. This region is strongly built, implying a well-developed coronoid process. Unfortunately, the whole posterior portion of the dentary is broken off.

Dentition.-The tooth implantation is acrodont (in terms of the location of implantation, where teeth are attached the crest of the jaw bone; see Jenkins et al., 2017). Teeth have blunt apices, so their appearance is rather rounded and they lack accessory cusps. The teeth increase in size posteriorly. In dorsal view, they are closely spaced. The tooth bases are more or less cylindrical, appear to touch one another, and, in at least some of the posterior teeth, overlap slightly, with the anterior edge of one

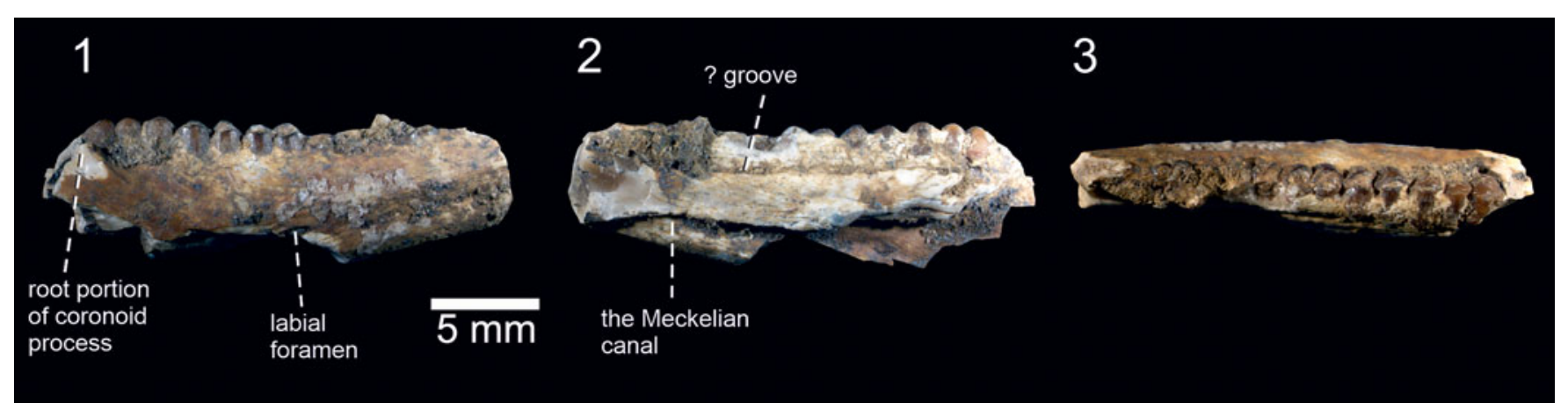

Figure 2. Right dentary of cf. Uromastyx s.l. sp. from the middle Miocene Palasava locality; VPL/PU/KPS-11 in: (1) lateral; (2) medial; and (3) dorsal views. 
tooth offset lingually relative to the posterior edge of the adjacent tooth (the imbricate alignment, sensu Čerňanský, 2011). No evidence of tooth replacement was found. Most of the crowns are highly abraded, especially those in the anterior region. The facets have a ventrolabial/dorsolingual orientation due to the dentary tooth row lying lingual to the maxillary tooth row (see Cooper and Poole, 1973).

Material._Right dentary VPL/PU/KPS-11.

Remarks. - The teeth are abraded, as frequently occurs in old agamid individuals. The dentary described here resembles that of Uromastyx s.l. in the following combination of features (e.g., Averianov and Danilov, 1996): (1) dentary heavily built; (2) the strong coronoid process (estimated based on the preserved basal portion); (3) blunt teeth with cylindrical bases, lacking accessory cusps; and (4) closely spaced teeth. Extant Uromastyx species are mainly herbivorous, which is correlated with shorter and deeper jaws than those of insectivorous forms (Herrel et al., 1999). Uromastyx is distributed in Africa and the Arabian Peninsula (Uetz et al., 2021), but a member of the genus Saara (S. hardwickii [Gay, 1827]), previously placed in Uromastyx, occurs in India today as well (Wilms et al., 2009; Uetz et al., 2021). For this reason, we use the term Uromastyx s.l. here. However, it should be noted that the coronoid process of the fossil dentary starts to rise at an unusual levelright behind the tooth row. In extant Uromastyx benti (Anderson, 1894) (Holmes et al., 2010a), extinct U. europaeus De Stefano, 1903, (e.g., Rage and Augé, 2015), and extant Indian S. hardwickii (see http://DigiMorph.org), there is a clearly visible gap between the end of the tooth row and the process. Although the gap is present in U. aegyptia as well (see http://DigiMorph.org), the bone starts to gradually rise dorsally more or less posterior to the tooth row in that species. However, some individual variations in the tooth row relating to this character cannot be fully excluded here. This can be seen in S. hardwickii, in which extension of the tooth row by additions posteriorly, as the jaw grows, was documented by Cooper and Poole (1973). All these factors can be resolved only by further studies, where various ontogenetical series of males and females of this clade will be CT-scanned and compared. In any case, the feature in the fossil dentary from the Palasava locality does not contradict the allocation presented here. The potential presence of a dental groove deserves a comment here. A similar groove, as is present in the Palasava specimen, can be seen in Uromastyx from the Oligocene of Egypt (Holmes et al., 2010a, fig. 4a) and in some extant members (although usually weakly developed; see http://DigiMorph.org).

\section{?Agamidae indet.}

Figure 3

\section{Occurrence.-Tapar, late Miocene.}

Description.-The material is poorly preserved; two small jaw fragments are available in the material (Fig. 3), both of which have two teeth attached to the bone. The otherwise smooth lateral portion of specimen BIOPS/CUP/KT-302 is pierced by a series of three small foramina (probably labial foramina).

Dentition.-Tooth implantation is acrodont. Teeth are mediolaterally compressed, triangular, with more or less pointed apices. The central cusp is dominant, whereas the mesial and distal accessory cusps are weak, almost unseparated from the central one. They form sharp, only slightly bulged, mesial and distal edges. The teeth are closely packed, so the interdental gaps are small.

Materials.-Two fragments of jaws BIOPS/CUP/KT-302 and BIOPS/CUP/KT-304.

Remarks.-The dentition type of the material from Tapar appears different from that of the material described above as cf. Uromastyx s.l. from the older Palasava locality-the teeth are more pointed and the incipient accessory cusp is present, although only weakly developed. This might indicate the presence of two agamid types. However, this interpretation needs to be viewed with caution. The anterior portion is not preserved, and thus the crucial diagnostic features are missing here. In contrast with chamaeleonids, agamids retain a trace of the primitive pleurodont condition (often in caniniform anterior teeth) in the anterior region (Moody, 1980). Moreover, the lingual walls of the teeth appear to be only very slightly taller than the labial walls. Thus, a subacrodont (subpleurodont, sensu Averianov and Danilov, 1996) condition present in agamids can be observed only weakly

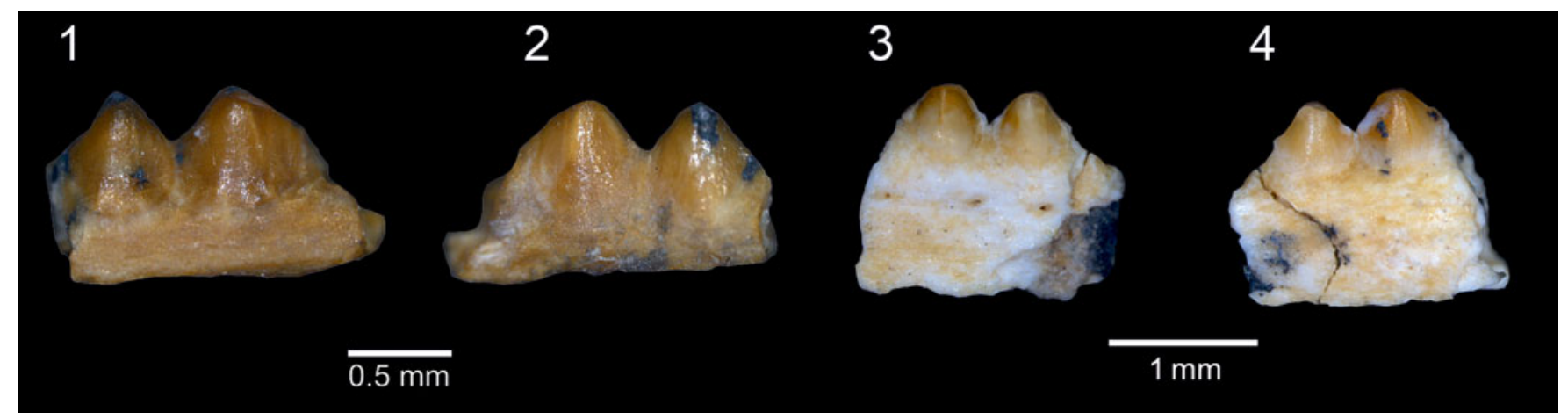

Figure 3. ?Agamidae indet. from the late Miocene Tapar locality; BIOPS/CUP/KT-304 (1, 2) and BIOPS/CUP/KT-302 (3, 4) in: $(\mathbf{1}, \mathbf{3})$ lateral; and $(\mathbf{2}, \mathbf{4})$ medial views. 
here. The allocation of such fragmentary material is therefore questionable, and chamaeleonids cannot be fully excluded as well (for fossil chamaeleonids, see e.g., Čerňanský, 2010, Čerňanský et al., 2020a).

$$
\begin{gathered}
\text { Scinciformata Vidal and Hedges, } 2005 \\
\text { Scincoidea Oppel, } 1811 \\
\text { Scincidae Gray, } 1825 \\
\text { Scincidae indet. } \\
\text { Figure } 4
\end{gathered}
$$

\section{Occurrence.-Tapar, late Miocene.}

Description.-The description is based on several dentaries, but all are only fragmentarily preserved (Fig. 4). The dentary is an anteroposteriorly elongated element with a narrow ventral section under the dental portion. In contrast, the alveolar crest, which supports teeth laterally, is high. The Meckelian canal is fully closed in the mid-region, but apparently open medially in the posterior section of the dentary. Although specimen VPL/PU/KT-718 represents the anterior portion of the dentary (note, however, that the anteriormost termination of this dentary is broken off and missing), no ventral opening of the Meckelian canal can be recognized here. Therefore, it can be estimated (if all specimens are conspecific; see Remarks) that any such opening was more likely small and located only in the anteriormost end of the dentary, rather than forming a longitudinal groove. The coronoid process is partly preserved-it slightly starts to rise dorsally, posterior to the tooth row. The process has a facet for the coronoid on its medial side. The smooth lateral surface of the bone is pierced by several labial foramina (at least three are present in VPL/PU/KT-718).

Dentition.-Tooth implantation is pleurodont. The teeth are slender and high. Dorsally, they extend above the alveolar crest by one-third of their length. Interdental gaps are present (i.e., teeth are not in contact). The tooth crowns have rounded apices, bearing labial and lingual cusps. The lingual portion of the tooth crowns between the culmines lateres bears fine apicobasal ridges. The tooth crowns are slightly mesiodistally wider than the tooth bases, which are more or less swollen lingually.

Materials._Five right dentaries: BIOPS/CUP/KT-300, BIOPS/ CUP/KT-301, VPL/PU/KT-717, VPL/PU/KT-718, and VPL/ PU/KT-780.

Remarks. - The most distinctive character of the Tapar skink dentaries is the partially closed Meckelian canal. It should be noted that all small skinks that develop the enclosed Meckel's groove tend to converge on a similar morphology. So very limited features, which are preserved in fragments from the Tapar locality, make them difficult to interpret. Moreover, even other clades that are present in India, such as geckos, have a closed Meckelian canal (e.g., Daza et al., 2014). The materials described here are also allocated to skinks based on their dentition (e.g., tooth crowns mesiodistally wide with apicobasal ridges and rounded apices, labial and lingual cusps present, interdental gaps present; see Kosma, 2004). However, an exception is VPL/PU/KT-718 (see Fig. 4.10, 4.11), in which only one tooth is preserved and, unfortunately, weathered. So in this particular specimen, its affinity to skinks cannot be strongly supported because we cannot exclude geckos here as well. Moreover, VPL/PU/KT-780 is completely without teeth, making allocation of this specimen difficult.

Among skinks, the closed Meckelian canal in the dentary can be observed in several lineages (Greer, 1970, 1974; Estes et al., 1988; Shea, 1999; Caputo, 2004; Hutchinson and Scanlon, 2009; Bolet et al., 2015; Čerňanský et al., 2020b; Čerňanský and Syromyatnikova, 2021): Mabuyinae, Egerniinae, Eugongylinae, Sphenomorphinae, Lygosominae, but also in Acontinae, whereas Scincinae and Ateuchosaurus have a fully open canal. The preserved morphology of the Tapar dentaries most resembles that of members of the clade Mabuyinae in the combination of the following features (Čerñanský et al., 2020b; Čerňanský and Syromyatnikova, 2021): (1) the closed Meckelian canal; (2) narrow ventral section under the dental portion relative to high alveolar crest; (3) close tooth spacing, including the level of the crowns; and (5) tooth crown morphology. One member of the mabuyines, Eutropis, occurs in the Territory of India (Mausfeld et al., 2002), but note that one taxon from Indochina, Toenayar novemcarinata (Anderson, 1871), has been separated from Eutropis and placed in the monotypic genus Toenayar (Karin et al., 2016). The fossil dentaries described here share some features with Eutropis (e.g., the assumed restriction of the anterior opening of the Meckelian canal-only based on the preserved morphology available to us), which is in contrast to the prolonged anterior opening present in the Middle Eastern lineage, Heremites (Čerňanský and Syromyatnikova, 2021). However, more complete material of this skink from Tapar is needed to support or exclude this claim. In any case, the fragmentary character of the currently available dentaries does not allow a precise allocation.

Anguimorpha Fürbringer, 1900

Varanidae Gray, 1827 (sensu Estes et al., 1988)

Genus Varanus Merrem, 1820

Type species. - Lacerta varia Shaw in White, 1790 (=Varanus varius) is the type species of the genus Varanus Merrem, 1820.

\section{Varanus sp. Figure 5}

Occurrence.-Palasava, middle Miocene.

Description.-Only one isolated, but more or less complete, vertebra is preserved (Fig. 5). It represents a dorsal vertebra. Its maximum anteroposterior length is slightly higher than the maximum dorsoventral height. In lateral view, the neural spine is moderately high, trapezoidal in shape (it gradually narrows posterodorsally). It is slightly posteriorly inclined, but does not exceed the condyle posteriorly. In dorsal view, the neural spine has a narrower appearance-it somewhat widens only in the posterior elevated section. Anteriorly, it continues to the low medial ridge, which runs to the end of the neural arch. The preand postzygapophyses are well expanded anterolaterally and posterolaterally. A deep interzygapophyseal constriction is 


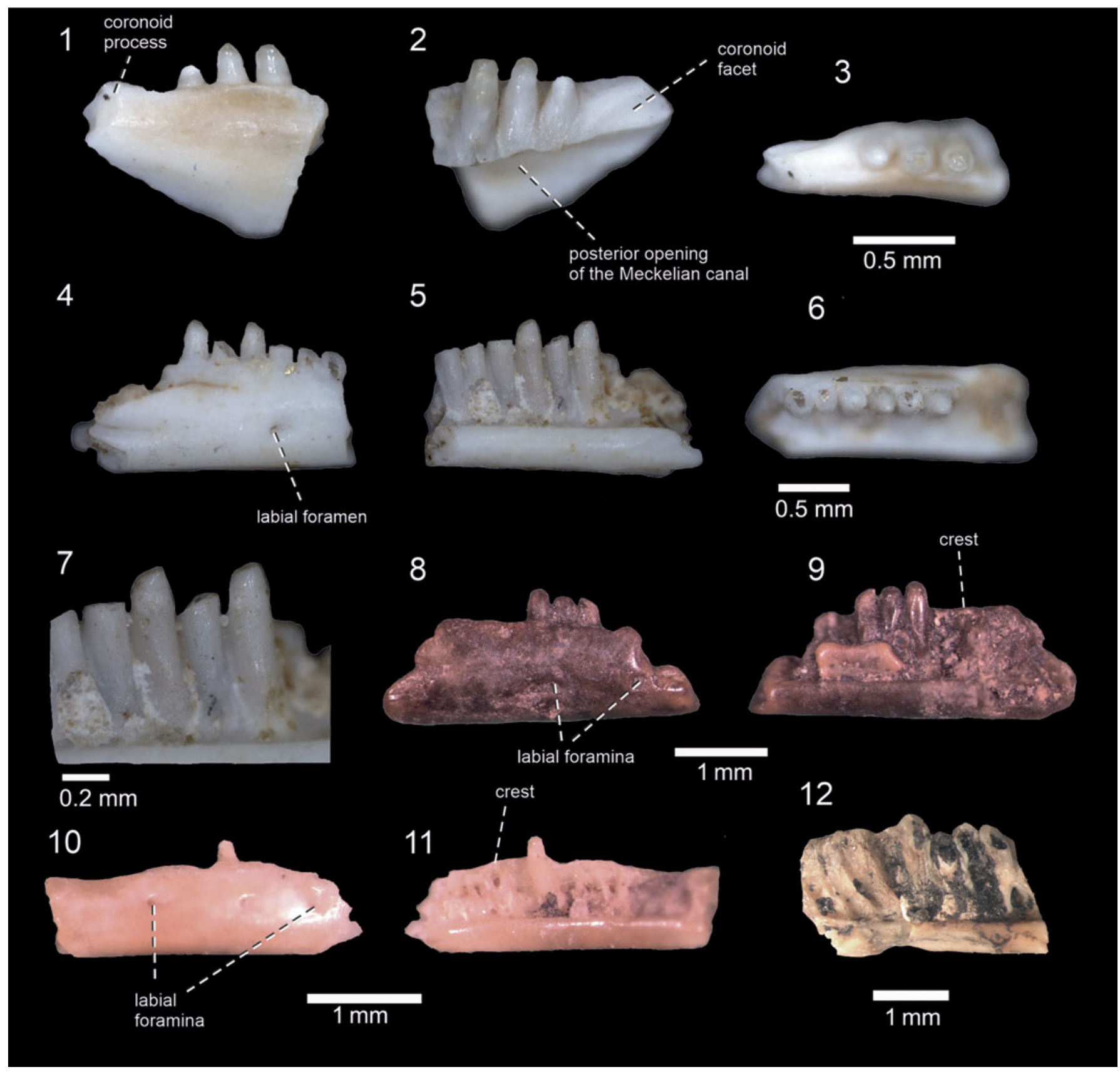

Figure 4. Right dentaries of Scincidae indet. from the late Miocene Tapar locality; BIOPS/CUP/KT-300 (1-3), BIOPS/CUP/KT-301 (4-7), VPL/PU/KT-717 $(\mathbf{8}, \mathbf{9})$, VPL/PU/KT-718 $(\mathbf{1 0}, \mathbf{1 1})$ and VPL/PU/KT-780 (12) in: $(\mathbf{1 , 4 , 8 , 1 0 )}$ lateral; $(\mathbf{2}, \mathbf{5}, \mathbf{9}, \mathbf{1 1}, \mathbf{1 2})$ medial with $(\mathbf{7})$ tooth detail; and $(\mathbf{3}, \mathbf{6})$ dorsal views.

present, located directly in front of the postzygapophyses. The articular facets on the pre-and postzygapophysis are ovoid, although those on the prezygapophyses appear to be larger. They are markedly inclined dorsally. The synapophysis is well developed, laterally expanded, and located anteriorly to the midpoint of the vertebra. It is almost a vertical structure, which extends to the entire height of the centrum. The neural canal is a tunnel-like structure (roughly pentagonal), noticeably smaller in height and width than the cotyle. The cotyle and condyle are markedly depressed. The articular surface of the condyle is exposed mainly dorsally, whereas the cotyle is exposed ventrally. In ventral view, the centrum is roughly triangular in shape. The lateral margins of the centrum (=subcentral ridges) gradually become closer posteriorly, with more or less straight courses along almost the entire section, but they become concave in the posteriormost region. Here, the distinct precondylar constriction is present. As a result, the condyle, with its slightly laterally expanded lateral margins, exceeds the width of the posterior portion of the centrum. The centrum is slightly convex in anterior view. In lateral view, the ventral margin of the centrum is straight.

Material.-One dorsal vertebra BIOPS/CUP/KP-240. 


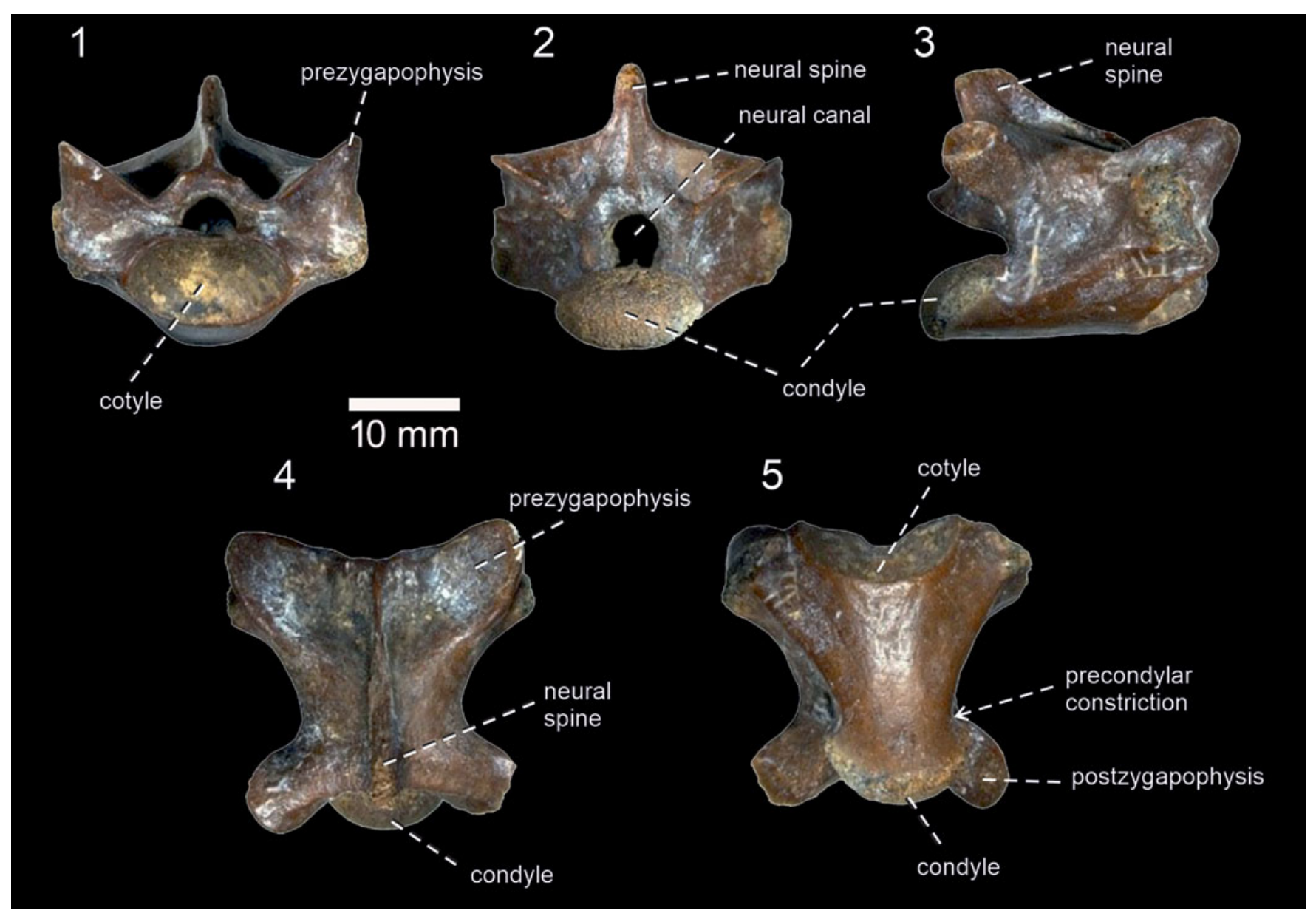

Figure 5. Varanus sp. from the middle Miocene Palasava locality; BIOPS/CUP/KP-240 in: (1) anterior; (2) posterior; (3) right lateral; (4) dorsal; and (5) ventral views.

Remarks. - The vertebra can be referred to Varanus on the basis of the markedly depressed cotyle and condyle, presence of a precondylar constriction, the articular surface of the condyle exposed dorsally with the cotyle exposed ventrally, and the presence of a well-demarcated anterior part (pars tectiformis) on the neural arch (Camp, 1923; Bailon and Rage, 1994; Venczel, 2006; Holmes et al., 2010b; Georgalis et al., 2018).

\section{Discussion}

In the following, we discuss the composition of lizard fauna at both localities separately.

The middle Miocene Palasava locality.-Two lizard clades can be recognized in the middle Miocene Palasava locality. In regards to paleoecology, the presence of Uromastyx s.l. is particularly interesting. Uromastyx and Leiolepis are remnants of one of the most ancient clades within Acrodonta (Moody, 1980; Gauthier et al., 2012). Although different species of Uromastyx occupy a variety of habitats, members of this genus are generally considered to be adapted to rather arid environments (Estes, 1983). Based on the occurrence of freshwater, terrestrial, estuarine, and marine taxa, however, Kapur et al. (2021) considered the Palasava locality to have been an environment with warm humid climatic conditions during the Miocene. Kapur et al. (2021) suggested a prevalence of woodland or forest, indicated by mammalian taxa such as a sanitheriid Sanitherium schlagintweiti von Meyer, 1866, an anthracothere Sivameryx palaeindicus Lydekker, 1877, rhinocerotid Brachypotherium perimense (Falconer and Cautley, 1847), and the proboscideans Zygolophodon, Gomphotherium, and Deinotherium living close to freshwater and marine environments (represented by cyprinids, turtles, freshwater crocodiles, the shark Carcharinus sp., the myliobatiform Myliobatis sp., and the pristid Pristis sp.). It is plausible that the uromastycine record from Palasava represents only an occasional appearance of the group in this region. But allochthony also can be assumed (i.e., the material could be just washed into the area from regions upstream, where micro-habitats such as elevations and dry plateau could be present). These factors play an important role in the vertical distribution of species (Černanský, 2016). In any case, it is rather unlikely that these lizards, members of which are arid-adapted today, lived permanently in the area of the Palasava locality. Note, however, that the Palasava specimen presumably represents an extinct uromastycine-its preferred habitat is therefore unknown. Interestingly, this situation is not unique. A similar ecological contradiction in regards of fossil 
uromastycine lizards is also observed at the Oligocene Fayum locality in Egypt, which has been reconstructed as a swampy riverine system (Holmes et al., 2010a).

The other lizard group here is represented by a monitor lizard assigned to Varanus. The fossil record of varanids is rather sparse in Asia (Lydekker, 1888; Rage et al., 2001; Malakhov, 2005; Suraprasit et al., 2016; Broin et al., 2020; for an up-to-date table with all early and middle Miocene occurrences of Varanus worldwide, see Georgalis et al., 2020a). The earliest confirmed Asian record of Varanus is reported from the early Miocene of Kazakhstan (Malakhov, 2005). Fossils referable to Varanus also have been reported from the early Miocene of the Murree Group in northwest Himalaya (Kumar and Kad, 2003), late Miocene of Afghanistan (Broin et al., 2020), late Miocene of Raun, Jammu (Rage et al., 2001), and middle Pleistocene of Thailand (Suraprasit et al., 2016). Varanus pronini has been reported from the middle Miocene of western Kazakhstan (Zerova and Chkhikvadze, 1986). In any case, the presence of Varanus in the middle Miocene of Palasava represents the oldest record of this taxon in the region of India south of the Himalayas. Varanus includes a clade of lizards that diversified into an exceptional range of body sizes, from the Komodo dragon (V. komodoensis Ouwens, 1912) to the pygmy monitors (V. brevicauda Boulenger, 1898, and V. primordius Mertens, 1942; see Collar et al., 2011). They represent mostly carnivorous (some frugivorous) forms that are widely distributed in tropical and subtropical regions (Pianka et al., 2004). The occurrence of this thermophilic reptile taxon in Palasava suggests a mean annual temperature that was not less than $\sim 15^{\circ} \mathrm{C}$ (Böhme, 2003).

Aside from the agamid and varanid described here, the squamate assemblage includes snakes: Acrochordus and Python (see Kapur et al., 2021; Singh et al., in press) that also support the environmental conditions of the locality (i.e., the members of Acrochordus are fully aquatic piscivores) (Shine, 1986) and Python is one of the most thermophilic squamates known (Shine, 1986; Slip and Shine, 1988; Snow et al., 2010; Ivanov and Böhme, 2011; Georgalis et al., 2020b).

The late Miocene Tapar locality.-Materials from the younger Tapar locality consist of acrodontan lizard jaw fragments, here questionably placed in agamids, and possibly a mabuyine skink. The potential presence of a mabuyine skink in the locality, as far as the fragmentary material can be interpreted, represents the first, but putative, evidence of this group in the Miocene of Asia. Although skinks are very successful and broadly distributed animals, comprising the largest, most diverse clade of lizards ( $25 \%$ of lizards in the world) (Whiting et al., 2003; Uetz et al., 2021), their fossil record is extremely poor. Based on molecular data, the Mabuyinae group has been suggested to have its origin in Southeast Asia (Greer, 1977; Honda et al., 2003; Mausfeld and Schmitz, 2003; Karin et al., 2016). However, the complete absence of a pre-Quaternary Asian fossil record causes a problem. Thus, although relatively younger than the suggested Paleogene origin of the group (Karin et al., 2016), the fossils from India would be consistent with the previous paleobiogeographic scenario based on molecular data. The Tapar material might show the potential occurrence of this clade in Asia at least as early as the Miocene (for other Miocene records, see
Čerňanský and Syromyatnikova, 2021). Unfortunately, the material, as stated previously, is very fragmentary, so our interpretation is tentative.

\section{Conclusions}

Three major clades can be identified in the materials: Agamidae, Scincidae, and Varanidae. Few elements of lizards are identifiable at the generic level. Although fragmentarily preserved, the materials here described provide a rare opportunity to observe, at least partly, the past lizard diversity in Asia. It sheds important light on the composition and paleobiogeographic distribution of squamates in the Indian subcontinent during the Miocene.

\section{Acknowledgments}

For English correction and advice, we are indebted to M. Hutchinson (South Australian Museum). For critical reading of the manuscript, we thank M. Augé (Muséum national d'Histoire naturelle, Paris) and G. Georgalis (Paläontologisches Institut und Museum, University of Zürich). We also thank H.D. Sues (editor). This work was supported by SERB-DST (HRR/ 2018/000063) and Central University of Punjab Bathinda for the Research Seed Money Grant (Ref. no: CUPB/CC/16/00/ 13). AČ acknowledges financial support from the Scientific Grant Agency of Ministry of Education of Slovak Republic and Slovak Academy of Sciences, Grant Nr. 1/0191/21. NPS and RKS also thank the Director, Wadia Institute of Himalayan Geology, Dehradun, for the research and facilities.

\section{References}

Anderson, J., 1871, A list of the reptilian accession to the Indian Museum, Calcutta, from 1865 to 1870 , with a description of some new species: The journal of the Asiatic Society of Bengal, v. 40, p. 12-39.

Anderson, J., 1894, On two new species of agamoid lizards from the Hardramut, south-eastern Arabia: The Annals and Magazine of Natural History; Zoology, Botany, and Geology, v. 14, p. 1-377.

Averianov, A., and Danilov, I., 1996, Agamid lizards (Reptilia, Sauria, Agamidae) from the early Eocene of Kyrgyzstan: Neues Jahrbuch für Geologie und Paläontologie Monatshefte, v. 12, p. 739-750. https://doi.org/10.1127/ njgpm/1996/1996/739.

Bailon, S., and Rage, J.-C., 1994, Squamates Néogène et Pléistocène du Rift Occidental, Ouganda, in Senut, B., and Pickford, M., eds., Geology and Palaeoecology of the Albertine Rift Valley, Uganda-Zaire: Palaeobiology. Orléans (France): CIFEG Occasional Publications, v. 2, p. $129-135$.

Bajpai, S., Domning, D., Das, D.P., Véléz-Juarbe, J., Mishra, V.P., 2010, A new fossil sirenian (Mammalia, Dugongidae) from the Miocene of India: Neues Jahrbuch für Geologie und Paläontologie Abhandlungen, v. 258, p. 39-50. https://doi.org/10.1127/0077-7749/2010/0082.

Bhandari, A., Mohabey, D.M., Bajpai, S., Tiwari, B.N., and Pickford, M., 2010, Early Miocene mammals from central Kutch (Gujarat) western India: implications for geochronology, biogeography, eustacy and intercontinental dispersals: Neues Jahrbuch für Geologie und Paläontologie Abhandlungen, v. 256, p. 69-97. https://doi.org/10.1127/0077-7749/2009/ 0034.

Bhandari, A., Pickford, M., and Tiwari, B.N., 2015, Basal late Miocene mammal fauna from Tapar and Pasuda, Kutch: Münchner Geowissenschaftliche Abhandlungen, Reihe A, v. 43, p. 1-38.

Bhandari, A., Kay, R.F., Williams, B.A., Tiwari, B.N., Bajpai, S., and Hieronymus, T., 2018, First record of the Miocene hominoid Sivapithecus from Kutch, Gujarat state, western India: PLoS ONE, 13:e0206314. https://doi. org/10.1371/journal.pone.0206314.

Bhandari, A., Bajpai, S., Flynn, L.J., Tiwari, B.N., and Mandal, N., 2021, First Miocene rodents from Kutch, western India: Historical Biology, https://doi. org/10.1080/08912963.2020.1870970. 
Biswas, S., 1992, Tertiary stratigraphy of Kutch: Journal of the Palaeontological Society of India, v. 37, p. 1-29.

Böhme, M. 2003, The Miocene climatic optimum: evidence from ectothermic vertebrates of Central Europe: Palaeogeography, Palaeoclimatology, Palaeoecology, v. 195, p. 389-401. https://doi.org/10.1016/S0031-0182(03) 00367-5.

Bolet, A., Daza, J.D., Augé, M.L., and Bauer, A.M. 2015, New genus and species names for the Eocene lizard Cadurcogekko rugosus Augé, 2005: Zootaxa, v. 3985, p. 265-274. https://doi.org/10.11646/zootaxa.3985.2.5

Boulenger, G.A., 1898, Third report on additions to the lizard collection in the Natural History Museum: Proceedings of the Zoological Society of London, v. 1898 , p. $912-923$

Broin, F. Lapparent de, Bailon, S., Augé, M.L., Rage, J.-C., 2020, Amphibians and reptiles from the Neogene of Afghanistan: Geodiversitas, v. 42, p. 409 426. https://doi.org/10.5252/geodiversitas2020v42a22.

Camp, C.L., 1923, A classification of the lizards: Bulletin of the American Museum of Natural History, v. 48, p. 289-481

Caputo, V., 2004, The cranial osteology and dentition in the scincid lizards of the genus Chalcides (Reptilia, Scincidae): Italian Journal of Zoology, v. 2, p. 35-45. https://doi.org/10.1080/11250000409356604.

Catuneanu, O., and Dave, A., 2017, Cenozoic sequence stratigraphy of the Kachchh Basin, India: Marine and Petroleum Geology, v. 86, p. 1106-1132.

Čerňanský, A., 2010, A revision of chamaeleonids from the lower Miocene of the Czech Republic with description of a new species of Chamaeleo (Squamata, Chamaeleonidae): Geobios, v. 43, p. 605-613. https://doi.org/10. 1016/j.geobios.2010.04.001

Črňanský, A., 2011, A revision of the chameleon species Chamaeleo pfeili Schleich (Squamata; Chamaeleonidae) with description of a new material of chamaeleonids from the Miocene deposits of southern Germany: Bulletin of Geosciences, v. 86, p. 275-282.

Černanský, A., 2016, Another piece of the puzzle: the first report on the early Miocene lizard fauna from Austria (Ottnangian, MN 4; Oberdorf locality): PalZ, v. 90, p. 723-746. https://doi.org/10.1007/s12542-016-0329-1.

Čerňanský, A., and Syromyatnikova, E.V., 2021, The first pre-Quaternary fossil record of the clade Mabuyidae; with a comment on the enclosure of the Meckelian canal in skinks: Papers in Palaeontology, v. 7, p. 195-215. https://doi.org/10.1002/spp2.1279.

Čerňanský, A., Herrel, A., Kibii, J.M., Anderson, C.V., Boistel, R., Lehmann, T., 2020a, The only complete articulated early Miocene chameleon skull (Rusinga Island, Kenya) suggests an African origin for Madagascar's endemic chameleons: Scientific Reports, v. 10, 109. https://doi.org/10. 1038/s41598-019-57014-5.

Čerňanský, A., Syromyatnikova, E.V., Kovalenko, E.S., Podurets, K.M., and Kaloyan, A.A., 2020b, The key to understanding the European Miocene Chalcides (Squamata, Scincidae) comes from Asia: the lizards of the East Siberian Tagay locality (Baikal Lake) in Russia: The Anatomical Record, v. 303, p. 1901-1934. https://doi.org/10.1002/ar.24289.

Collar, D.C., Schulte, J.A., and Losos, J.B., 2011, Evolution of extreme body size disparity in monitor lizards (Varanus): Evolution, v. 65, p. 2664 2680. https://doi.org/10.1111/j.1558-5646.2011.01335.x.

Cooper, J.S., and Poole, F.G., 1973, The dentition and dental tissues of the agamid lizard, Uromastyx: Journal of Zoology, London, v. 169, p. 85-100. https://doi.org/10.1111/j.1469-7998.1973.tb04654.x.

Cope, E.D., 1864, On the characters of the higher groups of Reptilia, Squamata and especially of the Diploglossa: Proceedings Academy of Natural Sciences of Philadelphia, v. 16, p. 224-231.

Datta, P.M., and Ray, S. 2006, Earliest lizard from the Late Triassic (Carnian) of India: Journal of Vertebrate Paleontology, v. 26, p. 795-800. https://doi.org/ 10.1671/0272-4634(2006)26[795:ELFTLT]2.0.CO;2

Daudin, F.M., 1802, Histoire Naturelle, Générale et Particulière des Reptiles: Paris, F. Dufart, v. 4, p. 1-397.

Daza, J.D., Bauer A.M., and Snively, E., 2014, On the gekkotan fossil record: The Anatomical Record, v. 297, p. 433-462. https://doi.org/10.1002/ar.22856.

De Stefano, G., 1903, I Sauri del Quercy appartenenti alla collezione Rossignol: Attidella Società Italiana di Scienze Naturali e del Museo Civico di Storia Naturale in Milano, v. 42, p. 382-418.

Estes, R., 1983, Sauria terrestria, Amphisbaenia: Handbuch der Paläoherpetologie, v. 10A: Stuttgart, New York, Fischer, 249 p.

Estes, R., de Queiroz, K., and Gauthier, J.A., 1988, Phylogenetic relationships within Squamata, in Estes, R., and Pregill, G.K., eds., Phylogenetic Relationships of the Lizard Families: Stanford, California, Stanford University Press, p. 119-281.

Falconer, H., 1868, On fossil species of Emys from the Sewalik Hills, referable to the existing Emys tecta (Bell), in Murchison, C., ed., Paleontological Memoirs and Notes of the late Hugh Falconer, V.I.: London, Robert Hardwicke, p. 382-388.

Falconer, H., and Cautley, P.T., 1847, Fauna antiqua sivalensis, being the fossil zoology of the Sewalik Hills, in the North of India Illustrations, part VIII: Suidae and Rhinocerotidae: London, Smith Elder, United Kingdom, pls. 69-80.
Forskål, P., 1775, Descriptiones animalium, avium, amphibiorum, piscium, insectorum, vermium; quae in itinere Orientali observavit Petrus Forskål: Hauniae [Heidelberg], Mölleri, 164 p.

Fürbringer, M., 1900, Zur Vergleichenden Anatomie Brustschulterapparates und der Schultermuskeln: Jenaische Zeitschrift für Naturwissenschaft, v. 34, p. 215-718. https://doi.org/10.5962/bhl.title.52377.

Gauthier, J.A., Kearney, M., Maisano, J.A., Rieppel, O., Behlke, A.D., 2012, Assembling the squamate tree of life: perspectives from the phenotype and the fossil record: Bulletin of the Peabody Museum of Natural History, v. $53,3-308$.

Geological Survey of India, 2012, Geology and mineral resources of Gujarat, Daman and Diu: Miscellaneous Publication Geological Survey of India, v. $30,85 \mathrm{p}$

Georgalis, G.L., Rage, J.-C., de Bonis, L., and Koufos, G., 2018, Lizards and snakes from the late Miocene hominoid locality of Ravin de la Pluie (Axios Valley, Greece): Swiss Journal of Geosciences, v. 111, p. 169181. https://doi.org/10.1007/s00015-017-0291-2.

Georgalis, G.L., Abdel Gawad, M.K., Hassan, S.M., El-Barkooky, A.N., and Hamdan, M.A., 2020a, Oldest co-occurrence of Varanus and Python from Africa-first record of squamates from the early Miocene of Moghra Formation, Western Desert, Egypt: PeerJ 8:e9092. https://doi.org/10.7717/ peerj. 9092.

Georgalis, G.L., Mayda, S., Alpagut, B., Sarbak, A., and Güler, G., 2020b, The westernmost Asian record of pythonids (Serpentes): the presence of Python in a Miocene hominoid locality of Anatolia: Journal of Vertebrate Paleontology, v. 40, e1781144. https://doi.org/10.1080/02724634.2020.1781144.

Gradstein, F.M., Ogg, J.G., Smith, A.G., Bleeker, W., and Lourens, L.J., 2004, A new geologic time scale, with special reference to Precambrian and Neogene: Episodes, v. 27, p. 83-100. https://doi.org/10.18814/epiiugs/2004/ v27i2/002

Gray, J.E., 1825, A synopsis of the genera of reptiles and Amphibia, with a description of some new species: Annals of Philosophy, v. 10, p. 193-217.

Gray, J.E., 1827, A synopsis of the genera of saurian reptiles, in which some new genera are indicated, and the others reviewed by actual examination: The Philosophical Magazine, or Annals of Chemistry, Mathematics, Astronomy, Natural History, and General Science, v. 2, p. 54-58. https://doi.org/ $10.1080 / 14786442708675620$.

Greer, A.E., 1970, A subfamilial classification of scincid lizards: Bulletin of the Museum of Comparative Zoology at Harvard College, v. 139, p. 151-184.

Greer, A.E., 1974, The generic relationships of the scincid lizard genus Leiolopisma and its relatives: Australian Journal of Zoology, v. 31, p. 1-67.

Greer, A.E., 1977, The systematics and evolutionary relationships of the scincid lizard genus Lygosoma: Journal of Natural History, v. 11, p. 515-540. https://doi.org/10.1080/00222937700770451.

Head, J.J., Mohabey, D.M., and Wilson, J.A., 2007, Acrochordus Hornstedt (Serpentes, Caenophidia) from the Miocene of Gujarat, Western India: temporal constraints on dispersal of a derived snake: Journal of Vertebrate Palaeontology, v. 27, p. 720-723.

Hedges, S.B., 2014, The high-level classification of skinks (Reptilia, Squamata, Scincomorpha): Zootaxa, v. 3765, p. 317-338. https://doi.org/10.11646/ zootaxa.3765.4.2.

Herrel, A., Aerts, P., Fret, J., and De Vree, F., 1999, Morphology of the feeding system in agamid lizards: ecological correlates: The Anatomical Record, v. 254 , p. 496-507. https://doi.org/10.1002/(SICI)1097-0185(19990401) 254:4<496::AID-AR5>3.0.CO;2-Q

Holmes, R.B., Murray, A.M., Chatrath, P., Attia, Y.S., and Simons, E.L., 2010a, Agamid lizard (Agamidae: Uromastycinae) from the lower Oligocene of Egypt: Historical Biology, v. 22, p. 215-223. https://doi.org/10. 1080/08912960903302128.

Holmes, R.B., Murray, A.M., Yousry, S., Attia, Y.S., Simons, E.L., and Chatrath, P., 2010b, Oldest known Varanus (Squamata: Varanidae) from the upper Eocene and lower Oligocene of Egypt: support for an African origin of the genus: Palaeontology, v. 53, p. 1099-1110. https://doi.org/10.1111/j. 1475-4983.2010.00994.x.

Honda, M., Ota, H., Köhler, G., Ineich, I., Chirio, L., Chen, S. L., and Hikida, T., 2003, Phylogeny of the lizard subfamily Lygosominae (Reptilia: Scincidae), with special reference to the origin of the new world taxa: Genes \& Genetic Systems, v. 78, p. 71-80. https://doi.org/10.1266/ggs.78.71.

Hutchinson, M.N., and Scanlon, J.D., 2009, New and unusual Plio-Pleistocene lizard (Reptilia: Scincidae) from Wellington Caves, New South Wales, Australia: Journal of Herpetology, v. 43, p. 139-147.

Hutchinson, M.N., Skinner, A., and Lee, M.S.Y., 2012, Tikiguania and the antiquity of squamate reptiles (lizards and snakes): Biology Letters, v. 8 , p. 665-669. https://doi.org/10.1098/rsbl.2011.1216.

Ivanov, M., and Böhme, M., 2011, Snakes from Griesbeckerzell (Langhian, Early Badenian), North Alpine Foreland Basin (Germany), with comments on the evolution of snake faunas in Central Europe during the Miocene climatic optimum: Geodiversitas, v. 33, 411-449. https://doi.org/10.5252/ g2011n3a2. 
Jenkins, K.M., Jones, M.E.H., Zikmund, T., Boyde, A., and Daza, J.D., 2017, A review of tooth implantation among rhynchocephalians (Lepidosauria): Journal of Herpetology, vol. 51, p. 300-306. https://doi.org/10.1670/16-146.

Joshi, M., and Kotlia, B.S., 2010, First report of the Late Pleistocene fossil lizards from Narmada Basin, Central India: Earth Science India, v. 3, p. 1-8.

Kapur, V.V., Pickford, M., Chauhan, G., and Thakkar, M.G., 2021, A middle Miocene $(\sim 14 \mathrm{Ma})$ vertebrate assemblage from Palasava, Rapar Taluka, Kutch (Kachchh) District, Gujarat State, western India: Historical Biology, v. 33, p. 595-615. https://doi.org/10.1080/08912963.2019.1648451.

Karin, B.R., Metallinou, M., Weinell, J.L., Jackman, T.R., and Bauer, A.M., 2016, Resolving the higher-order phylogenetic relationships of the circumtropical Mabuya group (Squamata: Scincidae): an out-of-Asia diversification: Molecular Phylogenetics \& Evolution, v. 102, p. 220-232. https:// doi.org/10.1016/j.ympev.2016.05.033.

Kosma, R., 2004, The Dentitions of Recent and Fossil Scincomorphan Lizards (Lacertilia, Squamata). Systematics, Functional Morphology, Paleoecology [Ph.D. dissertation]: Hannover, Germany, University of Hannover, 231 p.

Kumar, K., and Kad, S., 2003, Early Miocene vertebrates from the Murree Group, northwest Himalaya, India: affinities and age implications: Himalayan Geology, v. 24, p. 29-53.

Laurenti, J.N., 1768, Specimen Medicum, exhibens Synopsin Reptilium emendatam cum experimentis circa venena et antidota reptilium austracorum, quod authoritate et consensus: Viennae, Joan Thomae Nob. de Trattnern, $217 \mathrm{p}$.

Lydekker, R., 1876, Indian Tertiary and post-Tertiary Vertebrata. Descriptions of the molar teeth and other remains of Mammalia: Memoirs of the Geological Survey of India, v. 1, p. 19-83.

Lydekker, R., 1877, Notices of new and rare Mammals from the Siwaliks: Records of the Geological Survey of India, v. 10, p. 76-83.

Lydekker, R., 1880, Siwalik and Narbada Proboscidea: Memoirs of the Geological Survey of India, Palaeontologica Indica, v. 10, p. 182-300.

Lydekker, R., 1888, Catalogue of the Fossil Reptilia and Amphibia in the British Museum (Natural History): London, Taylor and Francis, 309 p. https:// doi.org/10.5962/bhl.title.61848.

Malakhov, D.V., 2005, The early Miocene herpetofauna of Ayakoz (Eastern Kazakhstan): Biota, v. 6, p. 29-35.

Mausfeld, P., and Schmitz, A., 2003, Molecular phylogeography, intraspecific variation and speciation of the Asian scincid lizard genus Eutropis Fitzinger, 1843 (Squamata: Reptilia: Scincidae): taxonomic and biogeographic implications: Organisms Diversity \& Evolution, v. 3, p. 161-171. https://doi.org/ 10.1078/1439-6092-00068.

Mausfeld, P., Schmitz, A., Böhme, W., Misof, B., Vrcibradic, D., and Rocha, C.F.D., 2002, Phylogenetic affinities of Mabuya atlantica Schmidt, 1945, endemic to the Atlantic Ocean archipelago of Fernando de Noronha (Brazil): necessity of partitioning the genus Mabuya Fitzinger, 1826 (Scincidae: Lygosominae): Zoologischer Anzeiger, v. 241, p. 281-293.

Merrem, B., 1820, Versuch eines Systems der Amphibien: Marburg, Germany, J.C. Kreiger, 191 p. https://doi.org/10.5962/bhl.title.5037.

Mertens, R., 1942, Ein weiterer neuer Waran aus Australien: Zoologischer Anzeiger, v. 137, p. 41-44.

Moody, S., 1980, Phylogenetic and Historical Biogeographical Relationships of the Genera in the Family Agamidae (Reptilia: Lacertilia) [Ph.D. dissertation]: Ann Arbor, Michigan, University of Michigan, 373 p.

Myers, N., Mittermeier, R.A., Mittermeier, C.G., da Fonseca, G.A.B., and Kent, J., 2000, Biodiversity hotspots for conservation priorities: Nature, v. 403 p. 853-858. https://doi.org/10.1038/35002501.

Oppel, M., 1811, Die Ordnungen, Familien und Gattungen der Reptilien als Prodrom einer Naturgeschichte derselben: München, J. Lindauer, 86 p. https://doi.org/10.5962/bhl.title.4911.

Ouwens, P.A., 1912, On a large Varanus species from the island of Komodo: Bulletin du Jardin Botanique de Buitenzorg, v. 6, p. 1-3.

Palot, M.J., 2015., A checklist of reptiles of Kerala, India: Journal of Threatened Taxa, v. 7, p. 8010-8022. http://dx.doi.org/10.11609/JoTT.2002.7.13.80108022 .

Patnaik, R., and Schleich, H.H., 1998, Fossil micro-reptiles from Pliocene Siwalik sediments of India: Veröffentlichungen aus dem Fuhlrott Museum, v. 4, p. 295-300.

Patnaik, R., Sharma, K., Mohan, L., Williams, B., Kay, R., and Chatrath, P., 2014, Additional vertebrate remains from the early Miocene of Kutch, Gujarat: Special Publications, Palaeontological Society of India, v. 5, p. 335-351.

Pianka, E.R., King, D.R., and King, R.A., 2004, Varanoid Lizards of the World: Bloomington, Indiana, Indiana University Press, 608 p.

Prasad, G.V.R, and Bajpai, S., 2008, Agamid lizards from the early Eocene of Western India: oldest Cenozoic lizards from South Asia: Palaeontologica Electronica, vol. 11, 1.4A. https://palaeo-electronica.org/2008_1/134/ index.html.

Prasad, K.N., 1962, Anthracotherids from Rapar Taluk, Kutch, Gujarat: Indian Mineralogy, v. 18, p. 92.
Prasad, K.N., 1964, Miocene vertebrates from Cutch District, Gujrat, India: Bulletin of the Geological Society of India, v. 1, p. 9-12.

Prasad, K.N., 1967, Fossil mammals of Cutch District, Gujrat, India: The Quarterly Journal of the Geological, Mining and Metallurgical Society of India, v. 39, p.187-192.

Rage, J.-C., and Augé, M.L., 2010, Squamate reptiles from the middle Eocene of Lissieu (France). A landmark in the middle Eocene of Europe: Geobios, v. 43 , p. $253-268$.

Rage, J.-C., and Augé, M., 2015, Valbro: a new site of vertebrates from the early Oligocene (MP 22) of France (Quercy) III-Amphibians and squamates: Annales de Paléontologie, v. 101, p. 29-41. http://dx.doi.org/10.1016/j. annpal.2014.10.002.

Rage, J.-C., Gupta, S.S., and Prasad, G.V., 2001, Amphibians and squamates from the Neogene Siwalik beds of Jammu and Kashmir, India: Paläontologische Zeitschrift, v. 75, p. 197-205. http://dx.doi.org/10.1007/ BF02988013.

Rage, J-C., Folie, A., Rana, R.S., Singh, H., Rose, K.D., and Smith, T, 2008, A diverse snake fauna from the early Eocene of Vastan Lignite Mine, Gujarat, India: Acta Palaeontologica Polonica, v. 53, p. 391-403. http://dx.doi.org/ 10.4202/app.2008.0303.

Raghavan, P., 1991, Fossil frogs and a lizard from the Basal Pinjor Formation (SubHimalaya), Haryana, India: Bulletin of the Panjab University, v. 42, p. 1-6.

Rana, R.S., Augé, M.L., Folie, A., Rose, K.D., Kumar, K., Singh, L., Sahni, A., and Smith, T., 2013, High diversity of acrodontan lizards in the early Eocene Vastan Lignite Mine of India: Geologica Belgica, v. 16, p. 290-301.

Sahni, A., and Mishra, V.P., 1975, Lower Tertiary vertebrates from western India: Monographs of the Palaeontological Society of India, v. 3, p. 1-48.

Sankhyan, A.R., and Čerňanský, A., 2016, A first possible chameleon from the late Miocene of India (the hominoid site of Haritalyangar): a tentative evidence for an Asian dispersal of chameleons: Science of Nature, v. 103, 94. https://doi.org/10.1007/s00114-016-1419-3.

Sharma, K.M., Singha, N.A., Patnaik, R., Tiwaria, R.P., Singh, N.P., Singha, Y.P., Choudhari, D., and Lalotra, S.K., 2021, Sharks and rays (chondrichthyes, elasmobranchii) from the Miocene sediments of Kutch, Gujarat, India: paleoenvironmental and paleobiogeographic implications: Historical Biology. https://doi.org/10.1080/08912963.2021.1893712.

Shea, G.M., 1999, Morphology and natural history of the Land Mullet Egernia major (Squamata: Scincidae): Australian Zoologist, v. 31, p. 351-364.

Shine, R., 1986, Sexual differences in morphology and niche utilization in an aquatic snake, Acrochordus arafurae: Oecologia, v. 69, p. 260-267.

Singh, N.P., Sharma, K.M., Patnaik, R., Singh, N.A., and Singh, Y.P., 2019, Teleostei fish remains from the Miocene of Kutch, Gujarat, India: palaeoenvironmental implications: Indian Journal of Geosciences, v. 73, p. 79-88.

Singh, N.P., Jukar, A.M., Patnaik, R., Sharma, K.M., Singh, N.A., and Singh, Y.P., 2020, The first specimen of Deinotherium indicum (Mammalia, Proboscidea, Deinotheriidae) from the late Miocene of Kutch, India: Journal of Paleontology, v. 94, p. 788-795. https://doi.org/10.1017/jpa.2020.3.

Singh, N.P., Patnaik, R., Cerňanský, A., Sharma, K.M., Singh, N.A., Choudhary, D., and Sehgal, R.K, in press, A new window to the fossil herpetofauna of India: amphibians and snakes from the Miocene localities of Kutch (Gujarat): Palaeobiodiversity and Palaeoenvironments.

Slip, D.J., and R. Shine, 1988, Reptilian endothermy: a field study of thermoregulation by brooding Diamond Pythons: Journal of Zoology, London, v. 216 , p. $367-378$.

Smith, K.T., Schaal, S., Sun, W., and Li, C.T., 2011, Acrodont iguanians (Squamata) from the middle Eocene of the Huadian Basin of Jilin Province, China, with a critique of the taxon "Tinosaurus": Vertebrata PalAsiatica, v. 49, p. 69-84.

Smith, T., Kumar, K., Ranac, R.S., Folie, A., Solé, F., Noiret, C., Steeman, T. Sahni, A., and Rose, K.D., 2016, New early Eocene vertebrate assemblage from western India reveals a mixed fauna of European and Gondwana affinities: Geoscience Frontiers, v. 7, p. 969-1001. https://doi.org/10.1016/j.gsf. 2016.05.001.

Snow, R., Wolf, A., Greeves, B., Cherkiss, M., Hill, R., and Mazzotti, F, 2010, Thermoregulation by a brooding Burmese Python (Python molurus bivittatus) in Florida: Southeastern Naturalist, v. 9, p. 403-405.

Spix, J.B. von, 1825, Animalia nova sive species nova lacertarum quas in itinere per Brasiliam annis MDCCCXVII-MDCCCXX jussu et auspicius Maximiliani Josephi I Bavariae Regis suscepto collegit et descripsit Dr. J.B. de Spix. Lipsiae: Monachii [Munich], T.O. Weigel, F.S. Hübschmanni, 26 p.

Suraprasit, K., Jaeger, J.-.J, Chaimanee, Y., Chavasseau, O., Yamee, C., Tian, P. and Panha, S., 2016, The middle Pleistocene vertebrate fauna from Khok Sung (Nakhon Ratchasima, Thailand): biochronological and paleobiogeographical implications: ZooKeys, v. 613, p. 1-157. https://doi.org/ 10.3897/zookeys.613.8309.

Theobald, W., 1868, Catalogue of the reptiles of British Burma, embracing the provinces of Pegu, Martaban, and Tenasserim; with description of new or little-known species: Journal of the Linnean Society London, Zoology, v. 10 , p. $4-67$. 
Thewissen, J.G.M., and Bajpai, S., 2009, A new Miocene sirenian from Kutch, India: Acta Palaeontologica Polonica, v. 54, p. 7-13. https://doi.org/10. 4202/app.2009.0102.

Uetz, P., Freed, P., and Hošek, J., eds., The Reptile Database: http://www.reptiledatabase.org. [accessed May 2021]

Venczel, M., 2006, Lizards from the late Miocene of Polgárdi (W-Hungary): Nymphea (Folia Naturae Bilhariae), v. 33, p. 25-38.

Vidal, N., and Hedges, S.B., 2005, The phylogeny of squamate reptiles (lizards, snakes, and amphisbaenians) inferred from nine nuclear protein-coding genes: Comptes Rendus Biologies, v. 328, p. 1000-1008. https://doi.org/ 10.1016/j.crvi.2005.10.001.

von Meyer, H., 1866, Ueber die Fossilen von Wirbeltieren welche die Herren von Schlagíntweit von Ihren Reísen Indien und Hochasien mittgebracht haben: Palaeontographica, Stuttgart, v. 15, p. 1-40.

White, J., 1790, Journal of a Voyage to New South Wales, with sixty-five plates of non descript animals, birds, lizards, serpents, curious cones of trees and other natural productions: London, Debrett, p. 229.
Whiting, A.S., Bauer, A.M., and Sites, J.W., Jr, 2003, Phylogenetic relationships and limb loss in sub-Saharan African scincene lizards (Squamata: Scincidae): Molecular Phylogenetics \& Evolution, v. 29, p. 582-598. https://doi.org/10.1016/s1055-7903(03)00142-8.

Wilms, T., Böhme, W., Wagner, P., Lutzmann, N., and Schmitz, A., 2009, On the phylogeny and taxonomy of the genus Uromastyx Merrem, 1820 (Reptilia: Squamata: Agamidae: Uromastycinae)—resurrection of the genus Saara Gray, 1845: Bonner Zoologische Beiträge, v. 56, p. 55-99.

Wynne, A.B., 1872, Memoir on the geology of Kutch, to accompany a map compiled by A. B., Wynne and F. Fedden, during the season 1867-68 and 1868-69: Memoirs of the Geological Survey of India, v. 9, p. 1-293.

Zerova, G.A., and Chkhikvadze, V.M., 1986, Neogene varanids of the USSR, in Roček, Z., ed., Studies in Herpetology: Prague, Charles University of Prague, p. 689-694.

Accepted: 5 August 2021 